論文

\title{
Work Index 相当数による石灰石の微粉砕性評価
}

\author{
神 田良照, 小 竹 直 哉*
}

\author{
A Evaluation of Fine Grinding of Limestone \\ by A Corresponding Work Index
}

by

Yoshiteru $\mathrm{KANDA}^{\dagger}$ and Naoya KoTAKE ${ }^{\dagger}$

Comminution is the oldest mechanical unit operation for size reduction of solid materials and an important step in many processes where raw materials are converted into intermediate or final products. Limestone is self-sufficient mineral resource in Japan and has been using as a sample for grinding tests.

Recently, a demand for fine or ultra-fine particles is increasing in many kinds of industries.

The energy efficiency of comminution is very low and the energy required for comminution increases with a decrease in feed or produced particle size. Research and development to find energy-saving comminution processes have been performed. Then, it is necessary to estimate the comminution energy. Bond had proposed Work Index and it is an important factor in designing comminution processes and has been widely used. The measurement procedure of Work Index is closely defined by JIS. In a previous paper, the authors proposed a corresponding Work Index which is proportional to the Work Index. A corresponding Work Index could be estimated by the examination of the zeroorder increasing rate constant of mass fraction less than a evaluating size using an arbitrary ball mill.

In this paper, ball mill, vibration mill and planetary mill grinding, compressive crushing of powder bed, and autogenous grinding with a stirred mill were carried out on limestone. The relationships between the corresponding Work Index and the evaluating size (sieving size) were studied.

As a result, the corresponding Work Index had the minimum value when the evaluating size was approximately the grain size of limestone in the five kinds of mills.

Key Words : Fine Grinding, Limestone, Grain Size, Work Index, Comminution Energy

† Department of Materials Science and Engineering, Yamagata University, 4-3-16, Jonan, Yonezawa, 992-8510, Japan 


\section{1. はじめに}

石灰石は，我が国で自給できる唯一の天然資源であ り，セメント工場や鉄鋼業に代表されるように多くの 工業で広く使われている1。著者らは，このような理 由から, 石灰石を代表的な試料のひとつとして選び, 物性の測定ならびに粉砕実験を行ってきている2,3)。そ して,これまでの実験，研究結果についてはまとめて 報告した ${ }^{4)}$ 。近年の科学技術, 工業の発展とともに粉 砕で扱われる固体原料の大きさはメー夕一級の塊から ナノメーター級のごく微小粒子まで $10^{9}$ オーダーの広 がりをむつようになってきている。粉砕は, 固体原料 に機械的エネルギーを加え, 破壊, 微細化していくき わめて単純な単位操作であるが，扱われる粒子径範囲 の広がり, 特に最近の微粒子領域への広がりととあに 多種多様な粉研機の開発が行われてきている。また, 日本国内で処理されている石灰石は年間約 2 億トンと 云われており, 粉砕プロセスに投入されるエネルギー あ膨大になっているので，わずかな省エネルギーの粉 砕機, プロセスの開発でも全体としては相当量のエネ ルギーが節約できることになる。これらのことを考え 合わせるに, 石灰石の物性之粉研操作とのかかわりを 実験, 検討することは欠かすことのできない研究課題 である。

このような観点から，本研究においては，代表的な 微粉砕操作5種類を選び, 石灰石の粉砕に要する仕事 量について検討した。その結果を以下に報告する。

\section{2. 石灰石の性質}

我が国で産出する石灰石は方解石の結晶からなる単 一鉱物の岩石で，不純物の少ない良質のものが多いと 云われている。したがって, 方解石の結晶サイズまで 細分しなけ机ば化学的, 物理的にもきわめて均質, 等 方的と見て良い国内産石灰石と一部の外国産石灰 石の力学的性質として，1）密度，2）圧縮強度，3）引 張強度，4）ヤング率，5）ポアソン比，6）縦波の速度, 7) ショア硬度，8）結晶状況，9）圧縮強度と引張強度 の関係，10）圧縮強度とヤング率の関係，11）引張強 度とショア硬度の関係，12）応力一ひずみ線図，その 他の物理的性質が成書 ${ }^{11}$ に紹介されているので参照さ れたい。

著者らがこれまで粉砕実験に用いてきた石灰石は主 に日鉄鉱業 (株) 井倉鉱業所産である。測定した力学的 物性值と粉砕に関係するであろう物性值を Table $1^{5 \sim 9)}$ に，また簡単な化学分析值を Table $2^{10)}$ に掲げた。

なお，これらの值はこれまでに用いてきた石灰石に ついてその都度測定してきた值をまとめたあのであり， 特に本実験に用いた石灰石について測定した物性值で はない。

実験用試料の調整は，井倉鉱業所より入手した数 $\mathrm{cm}$ の大きさの石灰石を人手とジョークラッシャーで 粗砕後, JIS 試験用ふるいを用いておおよう手ぶるい を行い，各粉研操作用に所定の粒子径範囲に整粒した。 そしてロータップシェーカーを用いて再度ふるい分け， 実験用試料とした。攪抖ミル用の粒子径 $20.0 \sim 13.0$ $\mathrm{mm}$ の大きい試料については粒子表面に付着してい

Table 1 Properties of limestone

\begin{tabular}{|c|c|c|c|c|c|c|c|c|c|c|c|}
\hline $\begin{array}{l}\text { Density } \\
\left(\mathrm{kg} \cdot \mathrm{m}^{-3}\right)\end{array}$ & $\begin{array}{l}\text { Moh's } \\
\text { hardness } \\
(-)\end{array}$ & $\begin{array}{l}\text { Vicker's } \\
\text { hardness } \\
\left(\mathrm{kgf} \cdot \mathrm{mm}^{-2}\right)\end{array}$ & \begin{tabular}{|l|} 
Young's \\
modulus \\
$(\mathrm{Pa})$
\end{tabular} & \begin{tabular}{|l|} 
Poisson's \\
ratio \\
$(-)$
\end{tabular} & \begin{tabular}{|l|} 
Compressive \\
stength $\left.^{\mathrm{a}}\right)$ \\
$(\mathrm{Pa})$
\end{tabular} & \begin{tabular}{|l|} 
Compressive \\
strengh of \\
sphere $^{b)}$ \\
$(-)$
\end{tabular} & \begin{tabular}{|l|} 
Shearing \\
strength $^{\mathrm{c}}$ \\
$(\mathrm{Pa})$
\end{tabular} & \begin{tabular}{|l|} 
Work \\
Index \\
$\left(\mathrm{kWh} \cdot \mathrm{t}^{-1}\right)$
\end{tabular} & $\begin{array}{l}\text { Hardgrove } \\
\text { Grindability } \\
\text { Index } \\
(-)\end{array}$ & $\begin{array}{l}\text { Percentage } \\
\text { of plastic } \\
\text { deformation } \\
\text { energy }(\%)\end{array}$ & $\begin{array}{l}\text { Grain } \\
\text { size } \\
(\mu \mathrm{m})\end{array}$ \\
\hline $2.70 \times 10^{3}$ & 4 & 110 & $6.80 \times 10^{10}$ & 0.32 & $9.57 \times 10^{7}$ & $4.15 \times 10^{6}$ & $1.79 \times 10^{7}$ & 9.40 & 13 & 55 & 16.3 \\
\hline
\end{tabular}

a) Cylindric specimen with a diameter $2 \mathrm{~cm}$ and a height $4 \mathrm{~cm}$ b) Spherical specimen with a diameter $2 \mathrm{~cm}$ c) Cubic specimen with a length $2 \mathrm{~cm}$

Table 2 Compositions of limestone (wt\%)

\begin{tabular}{|c|c|c|}
\hline $\mathrm{CaO}$ & $\mathrm{MgO}$ & Ig. loss \\
\hline 54.80 & 0.28 & 43.29 \\
\hline
\end{tabular}


る微粉を水で洗い，乾燥後，実験用試料とした。

\section{Work Index 相当数について}

著者らは，これまでに微粒域における砕料の粉砕性 を評価する指標として, Work Index ${ }^{11}$ (仕事指数)に 比例するWork Index 相当数を提案し ${ }^{122}$, 粉砕機 ${ }^{13)}$ あ るいは粉砕条件 ${ }^{12}$ の評価に関する問題に取り組んでき た。本論文を進めるにあたり，その説明が必要である ため,ここでも述べることにする。

はじめに, Work Index について説明すると, Work Index は，1952 年に Bond が提出した粉砕の仕事量に 関する第 3 理論に示されている砕料の粉砕抵抗（粉砕 のしにくさ）を表す指数であり, Eq. (1) の係数 $\mathrm{W}_{\mathrm{i}}$ $\left(\mathrm{kWh} \cdot \mathrm{t}^{-1}\right)$ で粉砕仕事量の推算に用いられる ${ }^{11}$ 。

$$
W=W_{\mathrm{i}}\left(\frac{10}{\sqrt{P}}-\frac{10}{\sqrt{F}}\right)
$$

ここで, $W\left(\mathrm{kWh} \cdot \mathrm{t}^{-1}\right)$ は粉砕仕事量, $F(\mu \mathrm{m}), P$ $(\mu \mathrm{m})$ はそれぞれ䂶料の粉砕前，粉砕後の $80 \%$ 通過 粒子径である。Work Index は, セメント工業, 鉱工 業で粉砝装置, 粉砕回路の設計および粉砕工程の管理 など広い範囲で利用されており ${ }^{14 \sim 16)}$, 一定規格のミル を用いて粉砕試験を行い，次式から算出する ${ }^{17,18}$ 。

$$
W_{\mathrm{i}}=\frac{1.1 \times 44.5}{P_{1}^{0.23} \cdot G_{\mathrm{bp}}^{0.82} \cdot\left(\frac{10}{\sqrt{P^{\prime}}}-\frac{10}{\sqrt{F}}\right)}
$$

ここで， $P_{1}(\mu \mathrm{m})$ は粉砕試験に用いるふるいの 目開き, $P^{\prime}(\mu m)$ は $P_{1}$ 以下の砕成物の $80 \%$ 通過粒 子径, $G_{\mathrm{pp}}\left(\mathrm{g} \cdot \mathrm{rev}^{-1}\right)$ はボールミル粉砕能である。

Work Index を求めるとき, ボールミル粉砕能 $G_{\mathrm{bp}}$ の測定が 1 番の問題となる。 $G_{\mathrm{bp}}$ は，ミル 1 回転当た りのふるいの目開き $P_{1}$ 以下の生成質量であるが， $G_{\mathrm{bp}}$ を測定するためには，循環率が 2.5 になるまで粉砕す ること，すなわち $P_{1}$ 以下の粒子の生成を， $1 /(1+2.5)$ $\times 100 \fallingdotseq 29 \%$ になるまで粉砕を行わなければならな い。この条件では, 例えば, 乾式連続粉砕で $P_{1}$ をシ ングルミクロン，あるいはサブミクロンオーダーで測 定することは極めて難しくなり ${ }^{19}$, 微粉砕, 超微粉砕 領域においては Work Index の測定が不可能になる ことを意味している。

そこで, 著者らはボールミル粉砕能の代わりに，任 意粒子径以下の生成速度定数を測定して算出する Work Index 相当数を提示した。
これまでの Work Index 測定に関する調査や研究 によれば，JIS になっている Eq. (2) で求める Work Index の値と, Bond が最初に提案した Eq. (3) ${ }^{11)}$ から 求められる值に大差のないことが報告されている200

$$
W_{\mathrm{i}}=1.1 \times 16\left(P_{1} / 100\right)^{0.5} G_{\mathrm{bp}}^{-0.82}
$$

Eq. (3) は，Eq. (2)に比べて単純であるので，著者ら は Eq. (3) を基にして Work Index 相当数を導き定義 した。

一般に, ボールミル粉研の初期に扔いて, フィード 粒子径に比べて十分に細かい粒子径 $x$ 。 以下の質量分 率 $Q_{\mathrm{xc}}(-)$ と, 粉砕時間 $t(\mathrm{~min})$ との間に次式の 0 次の生成速度式の成立が知られている ${ }^{21 ~ 23) 。 ~}$

$$
\frac{\mathrm{d} Q_{\mathrm{xc}}}{\mathrm{d} t}=k_{\mathrm{xc}}
$$

ここで, $k_{\mathrm{xc}}\left(\mathrm{min}^{-1}\right)$ は粒子径 $x_{\mathrm{c}}$ 以下の生成速度定数 である。 $x_{\mathrm{c}}(\mu \mathrm{m})$ は微粉砕性の評価に用いる粒子径 (評価粒子径) である。

Eq. (4) は

$$
Q_{\mathrm{xc}}=k_{\mathrm{xc}} t
$$

となり，粉砕時間 $t$ における粒子径 $x_{\mathrm{c}}$ 以下の生成質 量 $W_{\mathrm{xc}}(\mathrm{g})$ は Eq. (6) となる。

$$
W_{\mathrm{xc}}=Q_{\mathrm{xc}} W_{\mathrm{s}}=k_{\mathrm{xc}} W_{\mathrm{s}} t
$$

ここで, $W_{\mathrm{s}}(\mathrm{g})$ はフィード質量である。

$\mathrm{Eq}$. (6) の両辺を $t$ で除すと

$$
W_{\mathrm{xc}} / t=k_{\mathrm{xc}} W_{\mathrm{s}}
$$

$W_{\mathrm{xc}} / t$ は, 単位時間当たりの $x_{\mathrm{c}}$ 以下の生成質量であ るので, Eq. (3) のボールミル粉砕能 $G_{\text {bp }}\left(\mathrm{g} \cdot \mathrm{rev}^{-1}\right)$ と 比例関係が成り立つ。

$$
G_{\mathrm{bp}} \propto W_{\mathrm{xc}} / t=k_{\mathrm{xc}} W_{\mathrm{s}}
$$

さらに $P_{1}$ は，粉砕試験に用いるふるいの目開きであ るので, $P_{1} / 100 \propto x_{0}$ とおけ, Eq. (3) と Eq. (8) に より次式が導ける。

$$
\begin{aligned}
W_{\mathrm{i}}=1.1 \times 16\left(P_{1} / 100\right)^{0.5} G_{\mathrm{bp}}^{-0.82} & \propto\left(P_{1} / 100\right)^{0.5} G_{\mathrm{p}}^{-0.82} \\
& \propto x_{\mathrm{c}}^{0.5}\left(k_{\mathrm{xc}} W_{\mathrm{s}}\right)^{0.82}
\end{aligned}
$$

こうして, Work Index は Eq. (9) により簡略化する ことができる。Eq. (9) の右辺は Work Index に比例 する值であるので, 右辺を $W_{\mathrm{i}, \mathrm{c}}\left(\mu \mathrm{m}^{0.5} \cdot\left(\mathrm{g} \cdot \mathrm{min}^{-1}\right)^{-0.82}\right)$ とおいて Eq. (10) で表わし， $W_{\mathrm{i}, \mathrm{c}}$ をWork Index 相 当数と定義した。

$$
W_{\mathrm{i}, \mathrm{c}}=x_{\mathrm{c}}^{0.5}\left(k_{\mathrm{xc}} W_{\mathrm{s}}\right)^{-0.82}
$$

この指数を用いることによって, 砕料, 粉砕機あるい 
は粉砕条件の微粉砕性の評価がある程度可能になる。 本研究では, 代表的な粉砕操作である媒体ミル粉砕, 自生粉砕, 圧縮粉砕について, 5 種類の粉砕方法（粉 砕機）により, 石灰石の微粉砕性をWork Index 相当 数によって検討する。

\section{4. 媒体ミルによる粉砕}

媒体ミルは, 数多くの種類があり, 大きく分けると, 粉砕容器を駆動させて容器内の媒体 (ボール, ロッド など）に運動を生じさせ，砕料を粉砕するあのと，容 器内部に攪抖機構を備えて媒体に運動エネルギーを与 えることで粉砕するものがある。前者には, 容器が回 転する転動ミルや円振動する振動ミル, 自転する容器 に公転運動が加わる遊星ミルがある。また, 後者の攪 拌ミルにおいてあ様々な種類がある ${ }^{24)} 。$

ここでは, 最初に容器駆動式の媒体ミルを用いた結果 について述べる。

\section{1 実験装置}

実験に使用した媒体ミルは, 転動ミル, 振動ミル, 遊星ミルの 3 種類である。転動ミルは, Yamato（株） 製の実験用ミルで, 回転速度は $108 \mathrm{rpm}$ である。振動 ミルは, 中央化工機 (株) 製 MB-O 型ミルであり, 振 幅が $2 \times 2.4 \mathrm{~mm}$, 振動数が $1440 \mathrm{rpm}$ の円振動形式で, このときの振動強度（振動加速度/重力加速度）は 5.57 である。遊星ミルは, Fritsch (株) 製 P-5 であり, 支持盤とミル容器との中心間距離が $124 \mathrm{~mm}$, ミル公 転速度 $291 \mathrm{rpm}$, 自転速度は公転速度の 2.2 倍で, ミ ル容器は支持盤の回転（公転）にともない鈶直軸回り に支持盤と逆方向に回転（自転）する。このときの遠 心効果（遠心加速度/重力加速度）は 11.7 である。

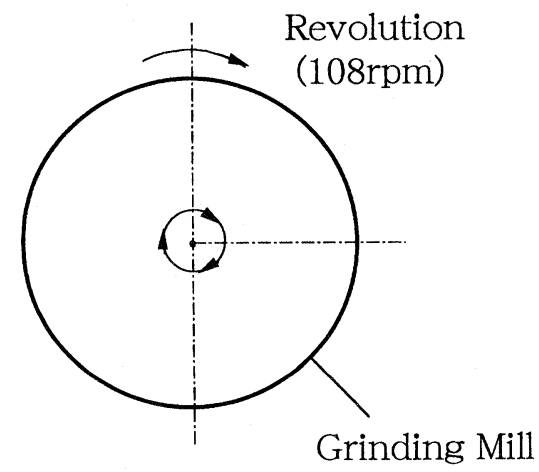

Fig. 1 Motion of ball mill

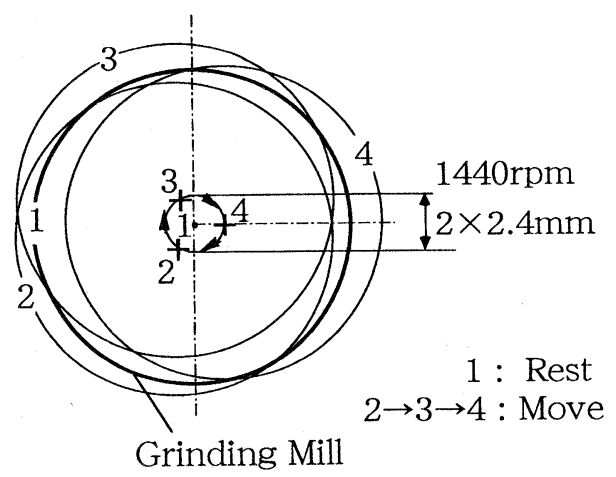

Fig. 2 Motion of vibration mill
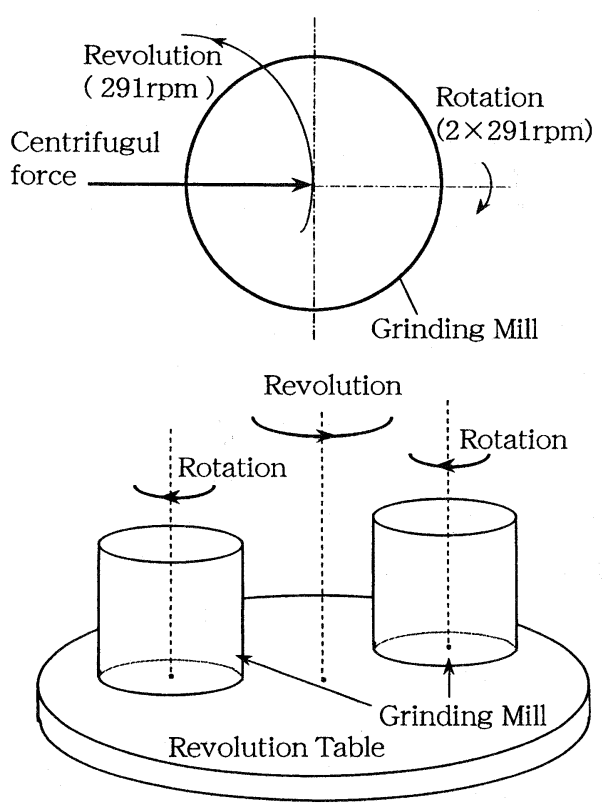

Fig. 3 Motion of planetary mill

Figs. $1 \sim 3$ に, これらの媒体ミルの運動状態の概略 を示す。転動ミル，振動ミルは装置の回転面または振 動面に対し正面から見た図であり，遊星ミルは装置全 体と装置公転面の真上から見たあのである。Table 3 に用いたミル容器および粉砕媒体に用いたボールの寸 法を示す。これらは，いずれあアルミナ製であり，各 媒体ミルの容器は, 内径と長さの比が一定となる相似 形のあのを使用した。また，媒体径は，転動ミルを基 準にしてミル内径に対して寸法比ができるだけ近くな るように選択した。 
Table 3 Dimensions of mill and sizes of media used

\begin{tabular}{lcccc}
\hline Kind of mill & $\begin{array}{c}\text { Volume of mill } \\
(\text { liter })\end{array}$ & $\begin{array}{c}\text { Inner diameter } \\
(\mathrm{mm})\end{array}$ & $\begin{array}{c}\text { Inner length } \\
(\mathrm{mm})\end{array}$ & $\begin{array}{c}\text { Ball diameter } \\
(\mathrm{mm})\end{array}$ \\
\hline Ball mill & 2.1 & 144 & 130 & 20 \\
\hline Vibration mill & 1.0 & 120 & 90 & 15 \\
\hline Planetary mill & 0.26 & 72 & 65 & 10 \\
\hline
\end{tabular}

\section{2 媒体ミルの粉碎条件の検討}

はじめに, 粉砕条件の基本であるフィード粒子径, フィード質量, 媒体質量を検討した。粉砕機の能力は, フィード粒子径の大きさと微粒子の生成量により評価

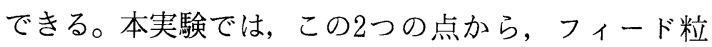
子径 $x_{\mathrm{f}}$ は Eq. (11) のフィード粒子の質量分率の減少 速度定数 $K_{1}$ が最大になる粒子径, フィード質量 $W_{\mathrm{s}}$, 媒体質量 $W_{\mathrm{B}}$ は Eq. (12) の目的物の生成速度定数 $k_{0}$ が最大を示す条件とした。

$$
\begin{aligned}
& -\frac{\mathrm{d} R}{\mathrm{~d} t}=K_{1} R \\
& \frac{\mathrm{d} W_{\mathrm{xc}}}{\mathrm{d} t}=k_{0}
\end{aligned}
$$

ここで, $R(-)$ はフィード粒子の質量分率, $K_{1}$ $\left(\mathrm{min}^{-1}\right)$ は減少速度定数, $W_{\mathrm{xc}}(\mathrm{g})$ は粒子径 $x_{\mathrm{c}}$ 以下の 生成質量, $k_{0}\left(\mathrm{~g} \cdot \mathrm{min}^{-1}\right)$ は生成速度定数, $t(\mathrm{~min})$ は粉砕時間である。

Eq. (11) は，これまでに砕料の単一粒子径成分の粉砕 時間による減少過程として, 各種媒体ミルに括いて成 立が認められている ${ }^{25 \sim 28)}$ 。Eq. (12) は, 転動ミル粉砕 の場合に成立することが知られておりり ${ }^{21233}$, 振動, 遊 星の両媒体ミルについても本実験で確認し, 粉砕条件 の評価に用いた。

転動ミルの実験結果の一例としてFig. 4 にフィード 粒子径による減少速度定数の変化, Fig. 5 にフィード 質量による生成速度定数の变化を示す。転動ミルの $K_{1}$ および $k_{0}$ は粉砕時間 $1,3,5$ 分の 3 点で調べた。両図 から $K_{1}$ を最大にするフィード粒子径と $k_{1}$ が最大にな るフィード質量の条件を見いだすことができる。ここ で $k_{0}$ の評価粒子径は, 特に理由はないが, 転動ミル の粉砕能力を十分に検討できると考え, フィード粒子 径の約 $1 / 6$ に当たる $150 \mu \mathrm{m}$ で評価した。

次に振動ミルについて検討した結果の例を Figs. 6, 7 に示す。振動ミルについては粉砕時間 0.5, 1, 2 分 の 3 点で調べた。転動ミルの結果と同様に, $K_{1}, k_{0}$

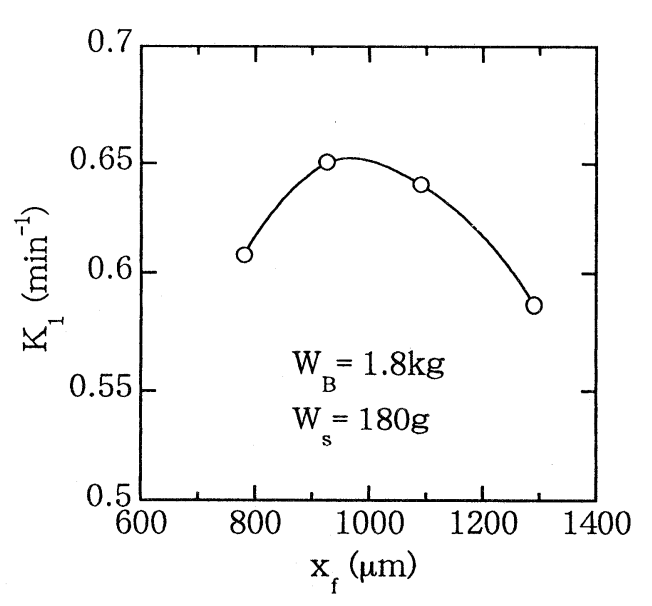

Fig. 4 Relationship between $K_{1}$ and feed size, $\mathrm{x}_{\mathrm{f}}$ (Ball mill)

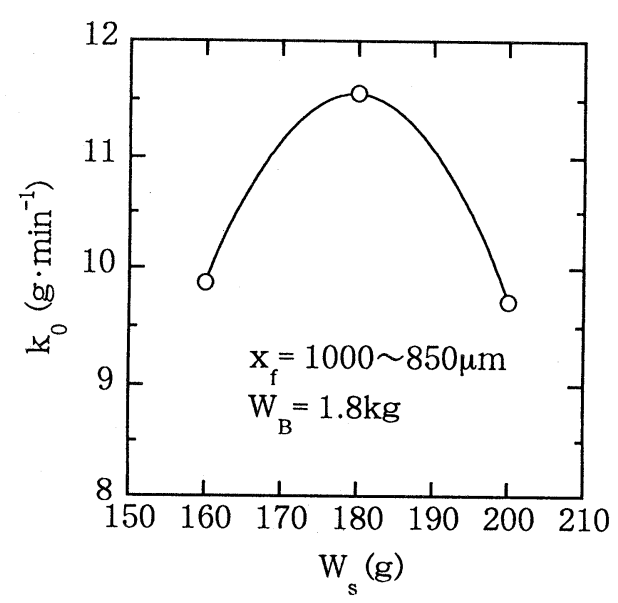

Fig. 5 Relationship between $\mathrm{k}_{0}$ and mass of feed, $\mathrm{W}_{\mathrm{s}}\left(\right.$ Ball mill, $\left.\mathrm{x}_{\mathrm{c}}=150 \mu \mathrm{m}\right)$

が最大になる条件が認められる。振動ミル粉砕にお いては, 転動ミルに比べ粉砕が短時間で進行するの で, $k_{0}$ の評価粒子径は, 転動ミルの場合より細かい $90 \mu \mathrm{m}$ とした。 


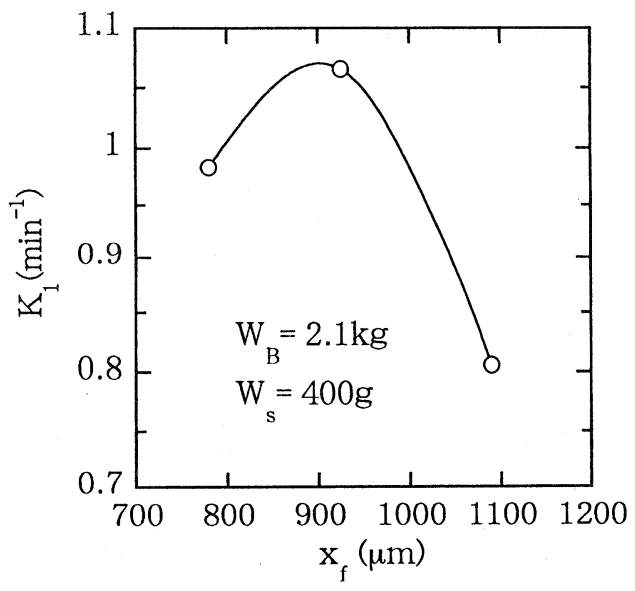

Fig. 6 Relationship between $\mathrm{K}_{1}$ and feed size, $\mathrm{x}_{\mathrm{f}}$ (Vibration mill)

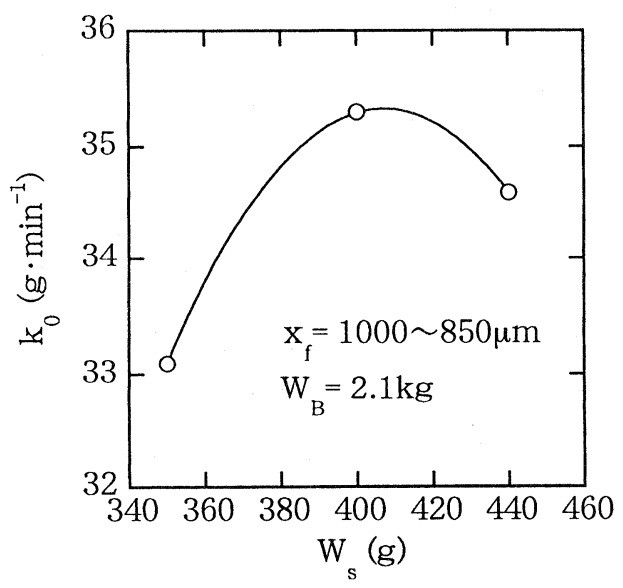

Fig. 7 Relationship between $\mathrm{k}_{0}$ and mass of feed, $W_{\mathrm{s}}$ (Vibration mill, $\mathrm{x}_{\mathrm{c}}=90 \mu \mathrm{m}$ )

Figs. 8，9 には遊星ミルの実験結果を示す。転動ミ ル, 振動ミルの場合と同様に $K_{1}, k_{0}$ が最大になる条 件を見いだすことができる。遊星ミルでは，前 2 者の 媒体ミルに比べ粉砕速度が速いため, 粉砕時間 0.5 分 の 1 点で行い, $k_{0}$ の評価粒子径は 3 種類の媒体ミルで 最む微小な約 $8 \mu \mathrm{m}$ にした。

このようにして決定した転動, 振動, 遊星ミルにお ける最適条件を Table 4 にまとめて示す。ここで，J はミル内容積に対する媒体の見かけ充てん率, $U$ は

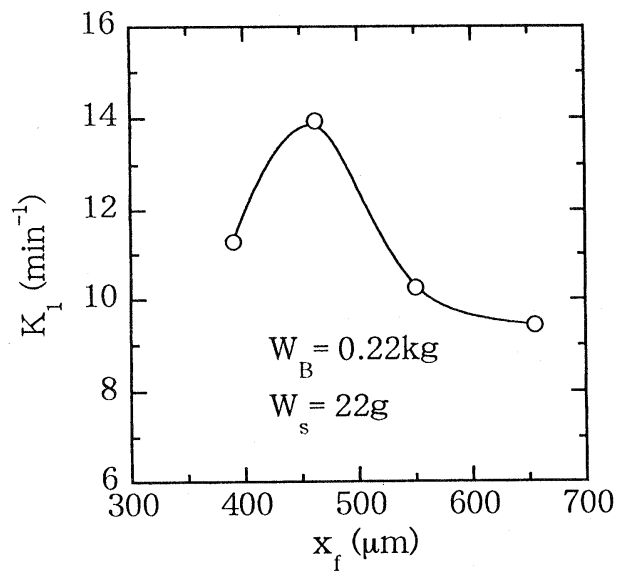

Fig. 8 Relationship between $K_{1}$ and feed size, $\mathrm{x}_{\mathrm{f}}$ (Planetary mill)

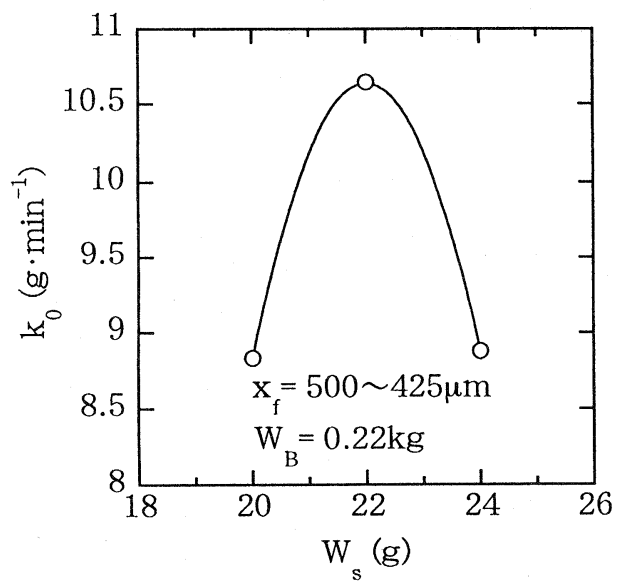

Fig. 9 Relationship between $\mathrm{k}_{0}$ and mass of feed, $\mathrm{W}_{\mathrm{s}}$ (Planetary mill, $\mathrm{x}_{\mathrm{c}}=8.4 \mu \mathrm{m}$ )

そのときの媒体の空隙体積に対する砕料の見かけ充て ん率である。 $J$ の最適値について, 転動ミル, 振動ミ ルは, 他の研究者の結果に近い值（転動ミルは $0.4 〜$ $0.5^{29)}$, 振動ミルは $\left.0.8 \sim 0.9^{273} 30,31\right)$ ) を示している。遊星 ミルでは，過去の研究による值 $\left(0.3^{32)}, 0.34^{33,34)}\right)$ に 比ベ, やや高い值になっているが, 遊星ミルが加速度 の大きい転動ミルと考えると, 本実験の結果のよう に両者の $J$ の最適値が近くなることも十分予想され る。 
Table 4 Optimum grinding conditions

\begin{tabular}{lccccc}
\hline Kind of mill & $\mathrm{x}_{\mathrm{f}}(\mu \mathrm{m})$ & $\mathrm{W}_{\mathrm{B}}(\mathrm{kg})$ & $\mathrm{W}_{\mathrm{s}}(\mathrm{g})$ & $\mathrm{J}(-)$ & $\mathrm{U}(-)$ \\
\hline Ball mill & $1000 \sim 850$ & 1.8 & 180 & 0.44 & 0.37 \\
\hline Vibration mill & $1000 \sim 850$ & 2.1 & 400 & 0.92 & 0.85 \\
\hline Planetary mill & $500 \sim 425$ & 0.22 & 22 & 0.45 & 0.35 \\
\hline
\end{tabular}

\section{3 媒体ミル粉砕による Work Index 相当数 $W_{\mathrm{i}, \text { 。 }}$ の測定}

\section{3. 1 実験方法}

4.2 で決定した粉砕条件によって，3 種類の媒体 ミ ルを用いて，所定時間毎に砕料を用意した完全回分粉 砕を行った。粉砕時間は，転動ミルは $5 \sim 60$ 分までの 6 点, 振動ミルは 1 ～30分までの 7 点, 遊星ミルは 20 秒〜 3 分までの 9 点である。砕成物の粒子径分布の测 定は，フィード粒子径〜 $75 \mu \mathrm{m}$ まではロータップシェー カーによる乾式ふるい分け，53〜20 $\mu \mathrm{m}$ までは超音波 槽で試料を分散しながらの湿式ふるい分けを行った。 $20 \mu \mathrm{m}$ 以下は分散媒にへキサメタりん酸ナトリウム $0.2 \mathrm{wt} \%$ 水溶液を用い，試料溶液を超音波槽で分散 させた後, レーザー光回折散乱法（日機装（株）製 Microtrac FRA）によって測定した。

\section{3. 2 生成速度定数 $k_{\mathrm{xc}}$ の測定}

Work Index 相当数の算出には Eq. (4) の生成速度 定数 $k_{\mathrm{xc}}$ の測定が重要である。

Figs. 10１2 に一例として, 粒子径 $x_{\mathrm{c}}$ が $7.5 \mu \mathrm{m}$ よ

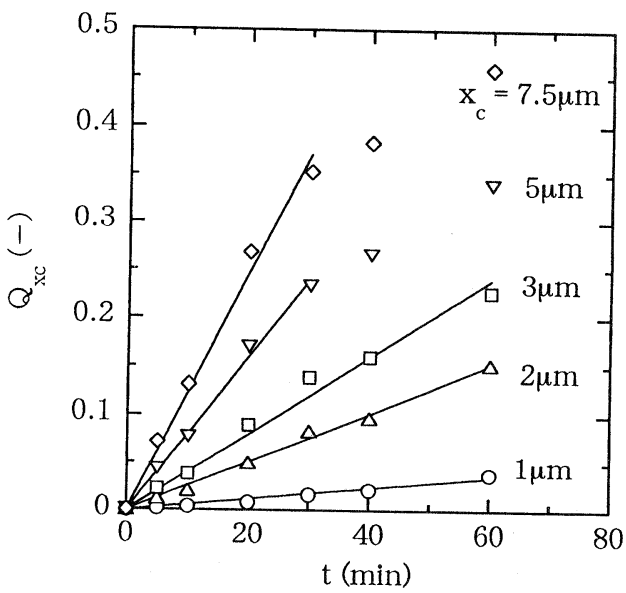

Fig. 10 Relationship between mass fraction finer than $\mathrm{x}_{\mathrm{c}}$ and grinding time (Ball mill)

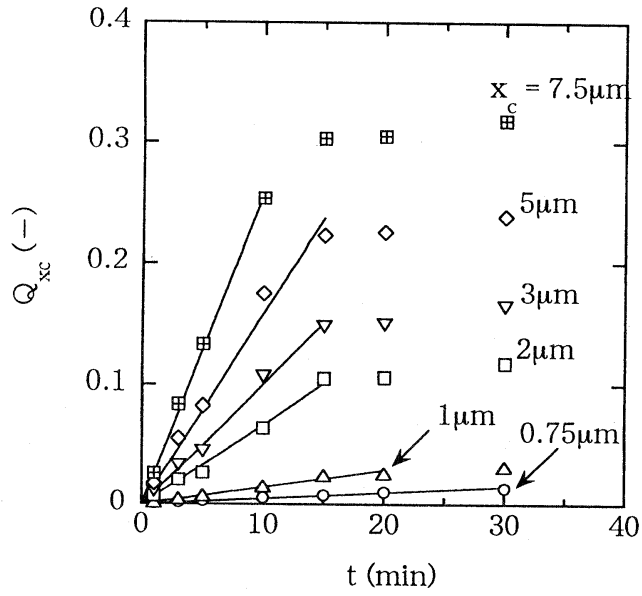

Fig. 11 Relationship between mass fraction finer than $x_{c}$ and grinding time (Vibration mill)

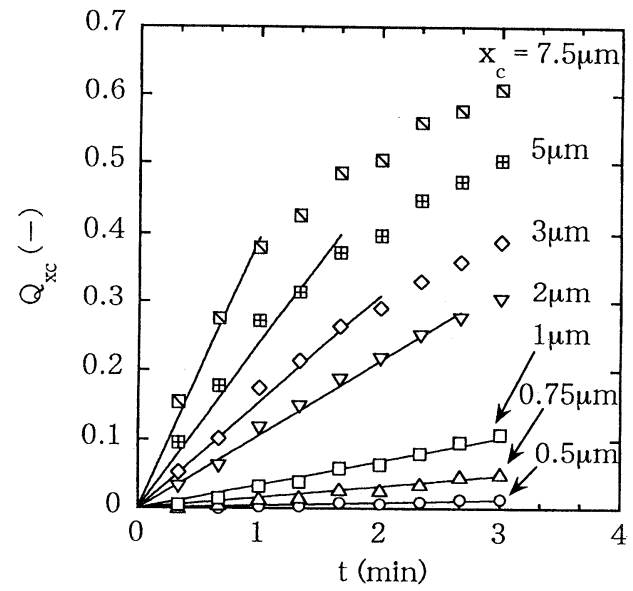

Fig. 12 Relationship between mass fraction finer than $\mathrm{x}_{\mathrm{c}}$ and grinding time (Planetary mill) 
り細いときの $x_{\mathrm{c}}$ 以下の生成分率と粉砕時間の関係を 転動, 振動, 遊星ミルの結果についてそれぞれ示す。 いずれの媒体ミルにおいても粉砕初期では Eq.(4)の 0 次の生成速度式が適用できることがわかる。

\section{3. 3 Work Index 相当数 $W_{\mathrm{i}, \mathrm{c}}$ の測定}

Fig. 13 には, 3 種類の媒体ミルについて前項で測 定した $k_{\mathrm{xc}}$ を Eq. (10)に代入して算出したWork Index 相当数と評価粒子径の関係を示す。Work Index 相当 数の評価粒子径による変化は, 媒体ミルの種類に関係 なく, 粒子径の減少とともに減少し, 10 数 $\mu \mathrm{m}$ 近辺 で最小值をとり, しだいに増加する傾向にある。この とき, Work Index 相当数が最小になる粒子径は, Table 1 に示した石灰石の結晶粒子径に非常に近いこ とがわかる。同様な結果は, 鉄鉱石についても得られ ている。石原 ${ }^{14)}$ はマレー・ヅングン産, 今西 ${ }^{35)}$ はブラ ジル産の鉄鉣石について, Work Index と粒子径の関 係を調へ，結晶粒子径あるいはそれに近いと思われる 粒子径を境に Work Index の急激な増加を指摘して いる。この原因として, 結晶粒子径より大きい範囲で は結晶粒界に沿った破壊（粒界破壊）が容易に進行す るが, 結晶粒子径より小さい粒子径の領域では粒内破 壊が必要になるため, 粉砕抵抗が増大すると考えられ ている。したがって, 同様な理由から, 石灰石の粉砕 性屯鉄鉱石のように結晶粒子径の近辺で粉砕抵抗が変 化することは十分に推察される。さらに, Fig.13の 結果は, Sikong ら ${ }^{36)}$ が, 弾性理論に基づき推定した 粒子径による脆性材料の破壊様式の変化によっても考 察される。これによると, 石灰石の破壊様式は，20〜

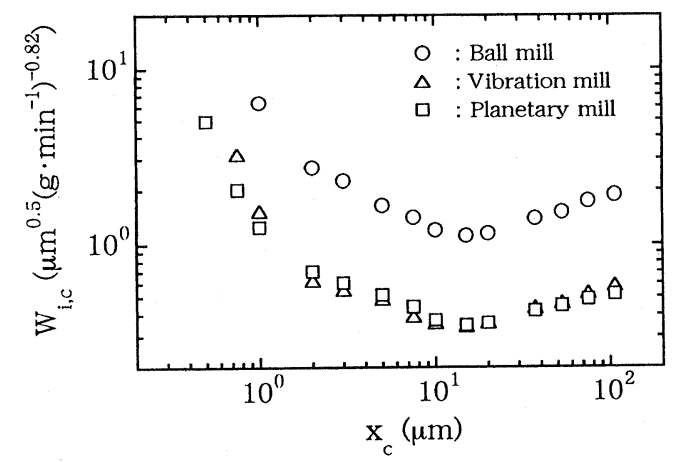

Fig. 13 Relationship between $\mathrm{W}_{\mathrm{i}, \mathrm{c}}$ and evaluating size, $\mathrm{x}_{\mathrm{c}}$ (Ball mill, Vibration mill, Planetary mill)
$30 \mu \mathrm{m}$ を境に，脆性破壊汃ら脆性破壊に加え，変形破 壊の加わる様式に移行し，この粒子径より小さくなる と弾性ひずみよりあ塑性ひずみの割合が相対的に大き くなるので粉砕抵抗が増加してくことを報告しており， 本実験の結果にもほぼ対応している。

つぎに, 媒体ミルの種類による石灰石の粉砕性を詳 しく見るために, Fig. 14 には, それぞれの媒体ミル で測定したWork Index 相当数を，その最小值 $W_{\mathrm{i}, \mathrm{mmin}}$ によって無次元化して表した值 $W_{\mathrm{i}, \mathrm{an}}\left(=W_{\mathrm{i}, \mathrm{e}} / W_{\mathrm{i}, \mathrm{min}}\right)$ の評価粒子径による変化を示す。石灰石の粉砕性は, 粉砕域全体では媒体ミルの種類の影響は小さいように 見られるが, $3 \mu \mathrm{m}$ 近辺以下の微粉砕域では転動ミル に比べ, 振動ミル, 遊星ミルが, よりすぐれている様 子がうかがえる。

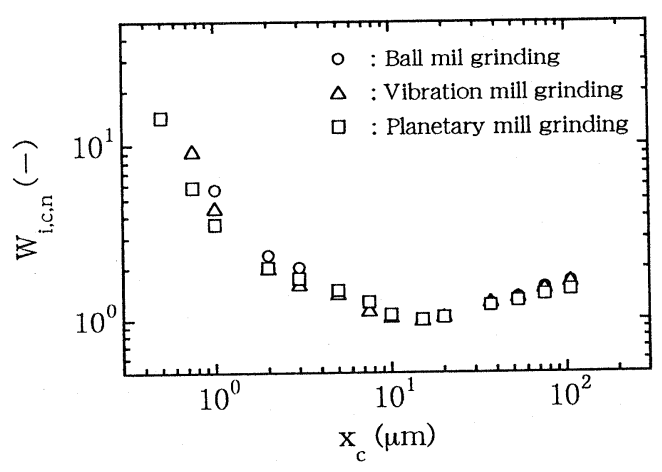

Fig. 14 Relationship between $\mathrm{W}_{\mathrm{i}, \mathrm{n} \mathrm{n}}$ and evaluating size, $\mathrm{x}_{\mathrm{c}}$ (Ball mill, Vibration mill, Planetary mill)

\section{5. 攪找ミルによる自生粉砕}

自生粉砕は，一般に大きさの異なる同一砕料を粉砕 機に装入し，大きい砕料を媒体として利用し，小さい 砕料を粉砕する方法である。自生粉砕の利点には, 同 一砕料を粉砕媒体に用いるため, 不純物の混入が少な いこと, 砕料の供給量を多くできることが挙げられる。 攪拌ミルは, 前節において述べたように, 攪拌作用 によって媒体に運動エネルギーを付与して砕料を粉砕 する方法が一般的な使い方である。しかし，ここでは 同体摩擦による微粒子製造法 ${ }^{37}$ の考え方をあとに，攪 拌ミルを自生粉砕に応用し, 比較的大きい単一粒子径 の石灰石を用いて粉砕実験を行い, Work Index 相当 
数による微粉砕性の評価を行う。

\section{1 実験装置}

実験に使用した摜拌ミルは，三井鉱山（株）製のア トライタ D 型であり, Fig. 15 に実験装置の概略を示 す。装置は(1)モーター, (2)卜ルクメーター, (4)粉砕装 置, (4)シグナルコンディショナー, (5)コンピューター

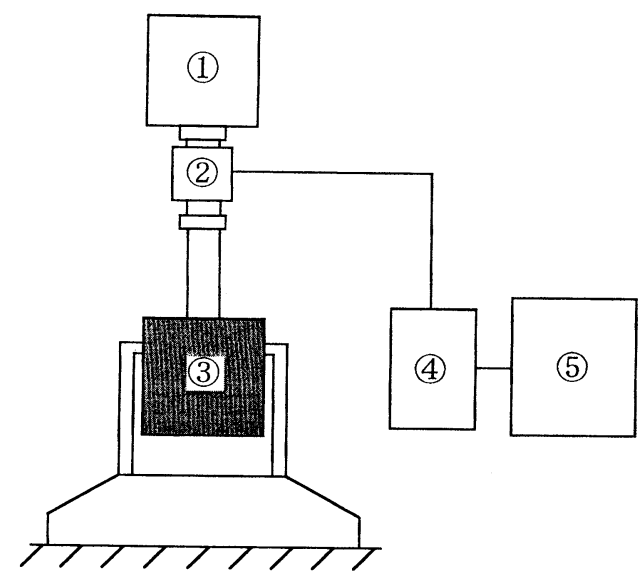
(1) Motor
(2) Torque meter
(3) Stirred mill
(5) Computer
(4) Signal conditioner

Fig. 15 Schematic diagram of experimental apparatus

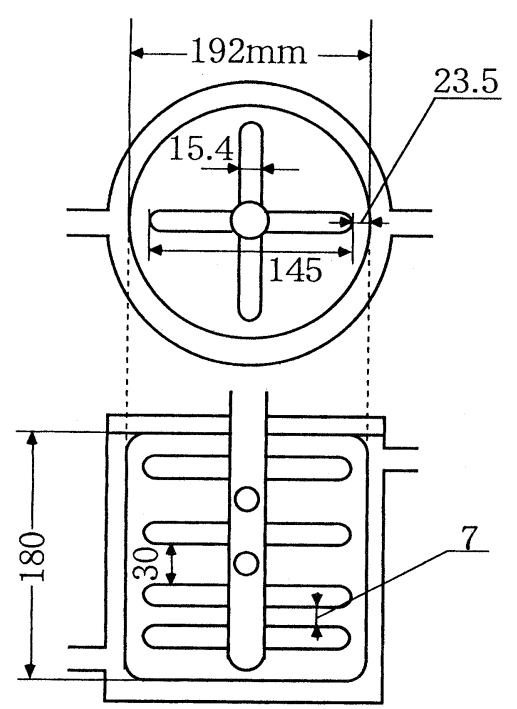

Fig. 16 Grinding apparatus (3) in Fig. 15)
で構成されている。Fig. 16 には粉砕装置の詳細を示 す。ミル容器は SUS 304 鋼板製の円筒形で, 内容積は $5.5 \ell て ゙ あ り$, 外周には冷却用のウォタージャケット が備え付けてある。攪拌翼は焼き入り鋼製の円柱形で, 回転軸に 12 本取り付けている。

\section{2 実験方法}

粉砕実験は, 砕成物の一部を微粒子の粒子径分布測 定用に採取し，残り全量をミルに戻して所定時間まで 粉砕を継続する半回分式であり, 粉砕時間は 2 分〜 180 分の 8 点である。石灰石のフィード質量は, ミル 容積の約 $70 \%$ に当たる $5 \mathrm{~kg}$ 一定とした。フィード粒 子径および覺拌翼回転速度は, サブミクロン粒子の生 成効率が, 最大になる条件とし, フィード粒子径は 20 13 mm, 攪找翼回転速度は $69 \mathrm{rpm}$ とした ${ }^{38)}$ 。粉 砕後の砕成物は, フィード粒子径 $149 \mu \mathrm{m}$ まではロー タップシェーカーによる乾式ふるい分けを行い, 149 $\mu \mathrm{m}$ 以下の砕成物は $70 \mathrm{~g}$ をサンプリングし，媒体ミ ル粉砕の場合と同様に湿式ふるい分けとレーザー光回 折散乱法を併用して粒子径分布の測定を行った。

また, 粉砕エネルギーは, Fig. 15 に示すように回 転軸に取り付けてあるトルクメーターからトルクを検 出し, 増幅した信号を $\mathrm{A} / \mathrm{D}$ コンバータを介してコン ピューターに取り込み, トルクと粉砕時間の関係を図 積分して算出した。

\section{3 㩭找ミルの自生粉砕による Work Index 相当} 数 $W_{\mathrm{i}, \mathrm{e}}{ }^{\prime}$ の測定

\section{3. 1 Work Index 相当数 $W_{\mathrm{i}, \mathrm{e}}$}

ここでは粉砕時間の代わりに粉砕エネルギーを基準 にした Work Index 相当数 $W_{\mathrm{i}, \mathrm{e}}{ }^{\prime}$ を以下のように定め る。

Eq. (4) において粉砕時間 $t$ (min) と粉砕エネルギー $\mathrm{E}(\mathrm{J})$ に比例関係があるので ${ }^{39}$, 次式が成り立つ。

$$
\frac{\mathrm{d} Q_{\mathrm{xc}}}{\mathrm{d} E}=k_{\mathrm{xc}}^{\prime}
$$

ここで $k_{\mathrm{xc}}{ }^{\prime}\left(\mathrm{J}^{-1}\right)$ は粒子径 $x_{\mathrm{c}}$ 以下の生成効率である。 Eq. (4)の $k_{\mathrm{xc}}$ の代わりに $k_{\mathrm{xc}}{ }^{\prime} を \mathrm{Eq}$. (10) に代入する と Work Index 相当数 $W_{\mathrm{i},{ }^{\prime}}\left(\mu \mathrm{m}^{0.5} \cdot\left(\mathrm{kg} \cdot \mathrm{J}^{-1}\right)^{-0.82}\right)$ が 得られる。

$$
W_{\mathrm{i}, \mathrm{c}}{ }^{\prime}=x_{\mathrm{c}}^{0.5}\left(k_{\mathrm{xc}}{ }^{\prime} W_{\mathrm{s}}\right)^{-0.82}
$$

\section{3. 2 Work Index 相当数 $W_{\mathrm{i}, \mathrm{c}}{ }^{\prime}$ の測定}

Fig. 17 に $x_{\mathrm{c}}=1 \sim 10 \mu \mathrm{m}$ のときの粒子径 $x_{\mathrm{c}}$ 以下の 生成分率と粉砕エネルギーの関係を示す。粉砕初期に 


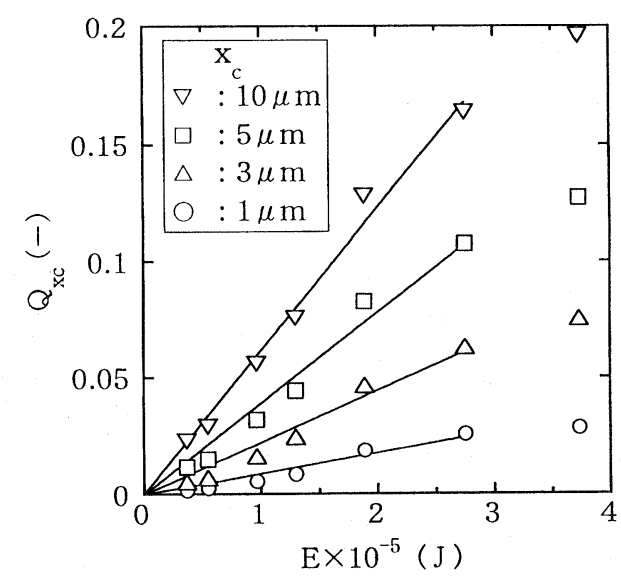

Fig. 17 Relationship between mass fraction finer than $x_{c}$ and grinding energy (Autogenous grinding with stirred mill)

おいて，両者の間に直線関係が認められ, Eq. (13) に より $k_{x \mathrm{xc}}{ }^{\prime}$ を求めることができる。Fig. 18 には Eq. (14) より計算したWork Index 相当数 $W_{\mathrm{i}, \mathrm{c}}{ }^{\prime}$ と評価粒子径 の関係を示す。この図を見ると， $W_{\mathrm{i}, \mathrm{c}}{ }^{\prime}$ は Fig. 13 の媒 体ミル粉砕の結果と同様に, 粒子径の減少ととあに減 少するが，20ないし $10 \mu \mathrm{m} \sim 2 \mu \mathrm{m}$ 近傍の粒子径では, ほぼ一定になり，この粒子径範囲より細かくなると増 加する様子がわかる。これは, 媒体ミルが粉砕媒体に よる衝撃力が主な粉砕作用であるのに対し, 攪汼ミル による自生粉砕では, フィード粒子同士のせん断力や

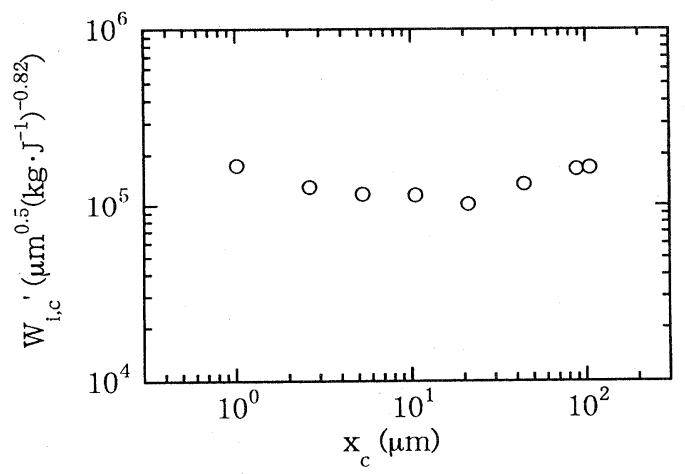

Fig. 18 Relationship between $\mathrm{W}_{\mathrm{i}, \mathrm{c}}{ }^{\prime}$ and evaluating size, $x_{c}$ (Autogenous grinding with stirred mill)
摩擦力による粉研作用（同体摩擦作用）が主であるた め，フィード粒子が大きいまま残存するが微粒子が生 成し易くなるため, 微粒域における結晶粒子径の影響 が小さくなり, 媒体ミル粉砕と異なる石灰石の粉砕性 を示すようになったと考えられる。

\section{6. 粉体層の圧縮粉砕}

セメント工業における, クリンカーの粉砕に転動ミ ルが広く利用されているが，粉砕プロセスの省力化の ために，近年，粉砕効率の良いローラーミルも用いら れるようになってきている(0)。ローラーミル粉砕の基 本となるのが, 粉体層の圧縮粉砕である。ここでは, 石灰石の粉体層の圧縮粉砕実験を行い，その微粉砕性 をWork Index 相当数により検討する。

\section{1 実験装置}

実験に用いた装置の概略をFig. 19 に示す。装置は (1)ペレット試験機, (2)荷重変換器, (3)荷重指示計, (4) 変位変換器, (5)変位指示計, (6)(7)粉砕装置, 8)コンピュー ターで構成されている。ペレット試験機は昭和測器 （株）製 PT-I型であり，荷重方式は下部耐圧盤の上 昇による圧縮である。Fig. 20 は, 粉砕装置の詳細で あり，(6)日と(7)杵は窒化ケイ素製である。

\section{2 実験方法}

粉砕は，臼に平らに充てんした粒子層に対し，圧縮 荷重を加えて行った。加えた圧縮荷重は, $10^{3} \mathrm{~N} \sim 10^{4}$ $\mathrm{N}$ 間の 6 種類で, この時粉体層に加わった圧力は, 実

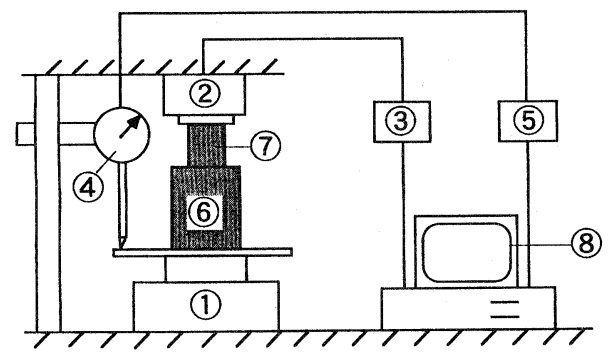

(1)Pellet testing machine, (2)Load cell, (3) Load cell indicater, (4) Differential transformer, (5)Displacement indicator, (6) Crushing vessel, (7)Plunger, (8) Computer

Fig. 19 Schematic diagram of experimental apparatus 


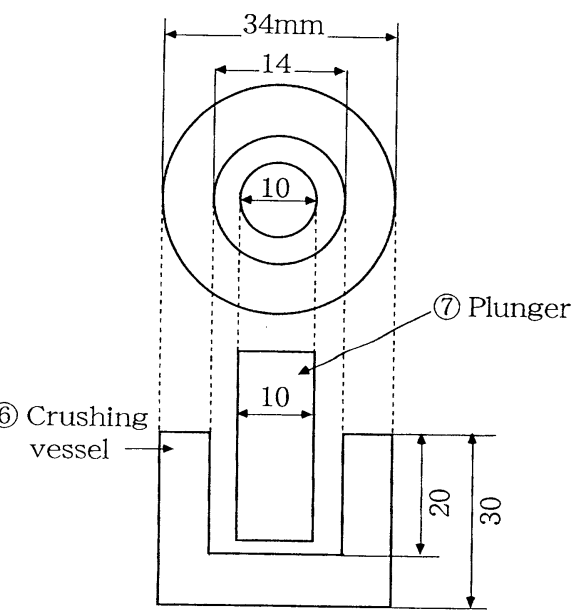

Fig. 20 Crushing apparatus (6), (7) in Fig. 19)

操業のローラーミルに近い值である。また, 変位速度 は装置の都合上 $0.5 \mathrm{~mm} \cdot \mathrm{min}^{-1}$ 一定とした。砕料のフィー ド粒子径は,これまでに, 寸法の異なる粉砕装置によ る実験に用いた粒子径 ${ }^{11}$ を参考に，1,400〜1,180 $\mu \mathrm{m}$ とした。フィード質量は, エネルギー効率（粉砕エネ ルギー/フィード粒子径より細かい砕成物質量）の良 い最適フィード質量の範囲が比較的広いこと ${ }^{41,422}$ と, 粒子径分布測定に最小限必要な質量を考え, みかけ上 7 ～層の粒子層を成す $1.6 \mathrm{~g}$ とした。

砕成物の粒子径分布は, フィード粒子径 $38 \mu \mathrm{m}$ ま では, 湿式ふるい分け, $38 \mu \mathrm{m}$ 以下は, 媒体ミル粉砕, 攪汼ミルの自生粉砕のときと同様にレーザー光回折散 乱法によって測定した。

また，粉体層に加えたエネルギーは，コンピューター に取り込まれた荷重-変位曲線を図積分して算出した。

\section{3 粉体層の圧縮粉砕による Work Index 相当数} $W_{\mathrm{i}, \mathrm{c}}{ }^{\prime}$ の測定

Fig. 21 に一例として粒子径 $x_{\mathrm{c}}=1 \sim 10 \mu \mathrm{m}$ のとき の $x_{\mathrm{c}}$ 以下の生成分率と粉砕エネルギーの関係を示す。 攪汼ミルによる自生粉砕の場合之同様に，両者の間に 直線関係が認められ，Eq. (13) の生成効率 $k_{\mathrm{xc}}{ }^{\prime}$ が求め られる。

この値を用いて Eq. (14) より算出したWork Index 相当数 $W_{\mathrm{i}, \mathrm{e}}{ }^{\prime}$ と評価粒子径の関係を Fig. 22 に示す。 粉体層の圧縮粉砕においては, Fig. 13 の媒体ミル粉 砕の場合と同様に， $W_{\mathrm{i}, \mathrm{c}}{ }^{\prime}$ が粒子径とともに連続的に

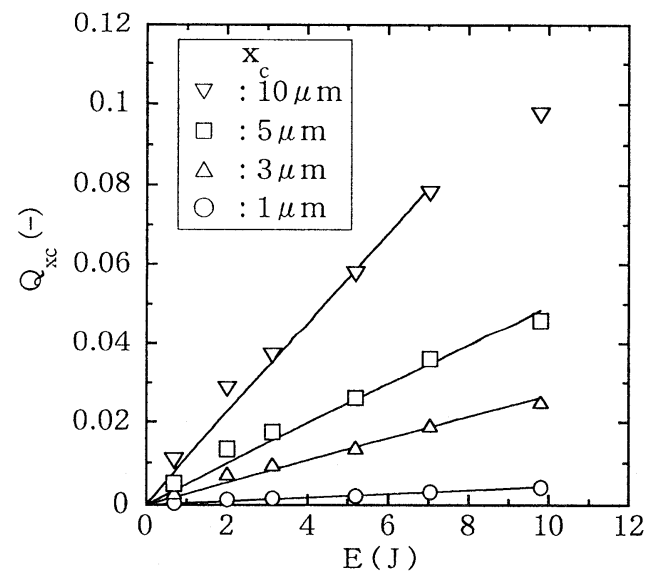

Fig. 21 Relationship between mass fraction finer than $x_{c}$ and grinding energy (Compressive crushing)

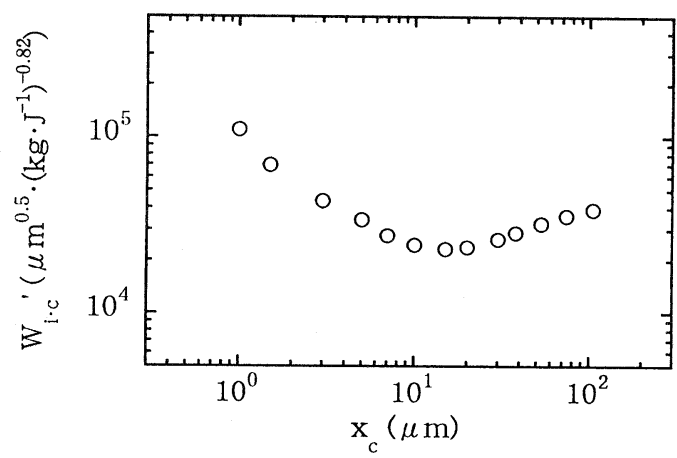

Fig. 22 Relationship between $\mathrm{W}_{\mathrm{i}, \mathrm{c}}$ and evaluating size, $\mathrm{x}_{\mathrm{c}}$ (Compressive crushing)

変化し, 結晶粒子径近傍で最小になることがわかる。 このことから石灰石の粉砕性は, 媒体ミル粉砕や圧縮 粉砕に対しては大きく変化しないことが予想される。

\section{7. 粉碎方法と石灰石の微粉砕性}

\section{1 粉碎方法の違いによる石灰石の Work Index 相当数の比較}

ここでは 4〜 6節で測定した石灰石の Work Index 相当数と評価粒子径の関係を比較する。Fig. 23 には, Work Index 相当数をそれぞれの最小值によって無次 元化した值 $W_{\mathrm{i}, \mathrm{c}, \mathrm{n}}$ と評価粒子径の関係を示す。この図 によると，石灰石の粉砕性におよぼす粉砕方法の影響 


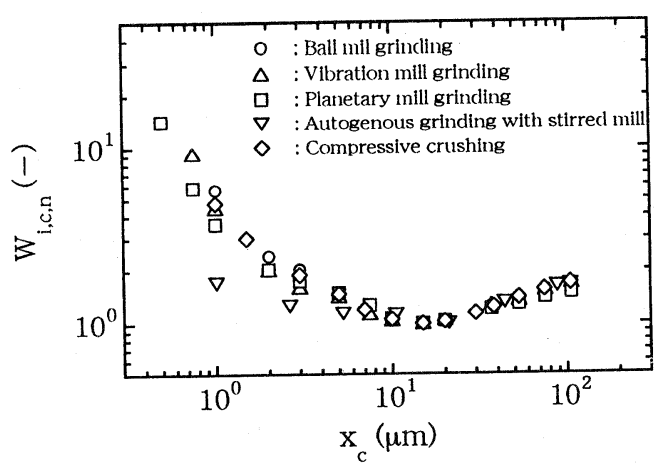

Fig. 23 Relationship between $W_{i, c, n}$ and evaluating size, $x_{0}$

は, 結晶粒子径近辺より大きい粒子径域では小さいと 見られるが, 結晶粒子径より小さい粒子径の範囲では, 粒子径の減少とともに，その差が大きくなっている。 特に攪拌ミルの自生粉砕では，媒体ミル粉砕や圧縮粉 砕に比へ, 石灰石の微粉砕性が大幅に改善される様子 がわかる。

Fig. 24 には, Work Index の測定に使用され, 工 業的に広く用いられる転動ミル粉砕から求めた $W_{\mathrm{i}, \mathrm{c}, \mathrm{n}}$ $\left(=\left(W_{\mathrm{i}, \mathrm{n}, \mathrm{n}}\right)_{\mathrm{B}}\right)$ を基準に, 他の粉砕方法による $W_{\mathrm{i}, \mathrm{c}, \mathrm{n}}$ を 相対的に表した結果を示す。この図から，石灰石の粉 砕性は, 転動ミル粉砕と圧縮粉砕では, ほぼ同じ傾向 にあるが, その他の方法では, 数 $\mu \mathrm{m}$ 以下の微粉砕 域になると, 振動ミル, 遊星ミル粉砕および攪拌ミル

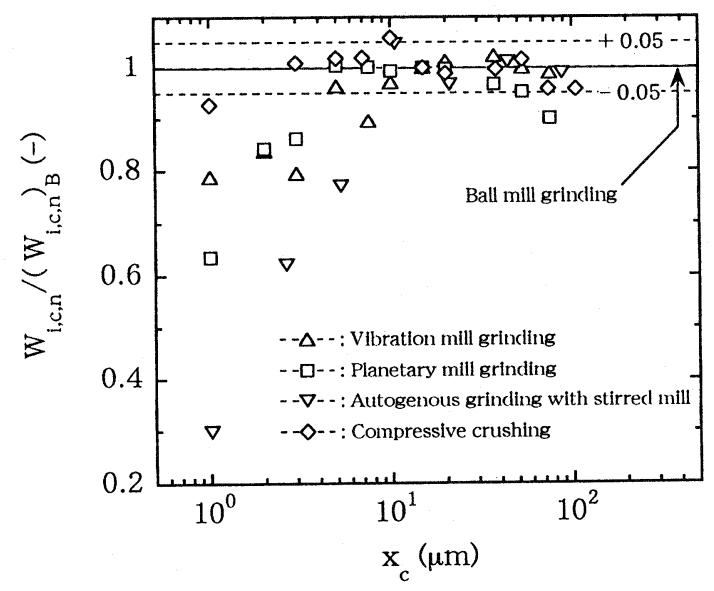

Fig. 24 Relationship between $\mathrm{W}_{\mathrm{i}, \mathrm{c}, \mathrm{n}} /\left(\mathrm{W}_{\mathrm{i}, \mathrm{c}, \mathrm{n}}\right)_{\mathrm{B}}$ and evaluating size, $\mathrm{x}_{\mathrm{c}}$
による自生粉砕が，転動ミル粉研に比べ良くなるのが わかる。これらの結果は, 石灰石の粉砕性に対して, 比較的大きい粒子径範囲については, 石灰石の力学的 特性（塑性的性質を含むことやャング率の荷重速度依 存性が小さいこと委など）が関与し，粉砕方法による 影響が少ないが, 数 $\mu \mathrm{m}$ 以下の微粒域では, 粉砕方 法による粉砕機構の違いが石灰石の粉砕性を変化させ ると考えられる。すなわち, 転動ミル粉砕は, 粉砕媒 体の砕料に対する衝撃力を主な粉砕機構とするのに対 し, 遊星ミル粉砕は, 衝撃力の他に媒体群によるせん 断力, 摩擦力による粉砕作用が加わり ${ }^{32}$, 攪拌ミルの 自生粉砕は, せん断力, 摩擦力を主な粉碟機構とする ために, 転動ミルに比べ微粉砕性が向上したと考えら れる。振動ミル粉砕については，これらの考察と Fig. 24 の結果をあわせて考えると, 遊星ミル粉砕のよう に衝撃力に加えて摩擦力などの粉砕作用が生じること で微粉砕性が良くなったと推察される。

以上のことをまとめると, 石灰石に対して, 衝撃力, 圧縮力を主とする粉砕様式では, 石灰石の粉砕性に及 ぼす影響は比較的小さいが，せ九断力あるいは摩擦力 による粉砕様式を取り入れることによって，石灰石の 数 $\mu \mathrm{m}$ 以下の微粉砕性を改善むしくは, 制御できる 可能性があると思われる。

\section{2 石灰石の粉砕仕事量の予測}

粉砕方法の違いによって数 $\mu \mathrm{m}$ 以下の石灰石の微 粉砕性が变化することを示したが, この様子を粉砕仕 事量を計算することで，より詳しく検討する。

石灰石の粉砕仕事量は, Eq. (1) を基に, 微粒域にお けるWork Index の変化を, $100 \mu \mathrm{m}$ のときの Work Index 相当数を基準にし, Work Index 相当数の粒子 径による変化率を乗じることによって推定する次式を 用いて計算した。

$$
W=\frac{W_{\mathrm{i}, \mathrm{c}}}{W_{\mathrm{i}, \mathrm{c}}(100)} W_{\mathrm{i}}(\mathrm{C})\left(\frac{10}{\sqrt{P}}-\frac{10}{\sqrt{F}}\right)
$$

ここで, $W_{\mathrm{i}, \mathrm{c}}(100)$ は, 評価粒子径が $100 \mu \mathrm{m}$ のとき の Work Index 相当数, $W_{\mathrm{i}}$ (C) は Constant Work Index である。Constant Work Index は, Bond が定 義した, 粒子径 $100 \mu \mathrm{m}$ のときの Work Index であ $る^{44}$ 。ここで, Work Index の值は, 生成粒子径 $P$ に 近い大きさの粒子径で測定することが望ましいので, 仕事量の計算には粒子径 $x_{\mathrm{c}}$ と粒子径 $P$ は等しいと仮 定している。また, フィード粒子径 $F$ の値は, 転動ミ 
ルが $1,850 \mu \mathrm{m}$, 振動ミルが $925 \mu \mathrm{m}$, 遊星ミルが 463 $\mu \mathrm{m}$, 攪拌ミルは $16,500 \mu \mathrm{m}$, 圧縮粉砕は $1,290 \mu \mathrm{m}$ である。Fig. 25 には, 粉砕仕事量 $W$ と粒子径 $P$ の関 係を示す。これによると，攪拌ミルによる自生粉砕は, $2 \sim 3 \mu \mathrm{m}$ 近傍以下の微粒域において, 粉砕仕事量が, 他の方法に比較して低くなっており，微粉砕にすぐれ ていることがわかる。また, 数 $\mu \mathrm{m}$ 数 $10 \mu \mathrm{m}$ の実操 業に招ける粉砕領域では, 粉砕方法によって, 粉砕仕 事量には大差のない様子がわかる。このことは，異な る粉砕方法を用いても, 例えば, 粉砕条件をうまく調 整し, Work Index を適切に管理することによって石 灰石の粉砕仕事量を一様に制御できることを示してお り, Work Index の実操業における有効性を示すすの と考えられる。

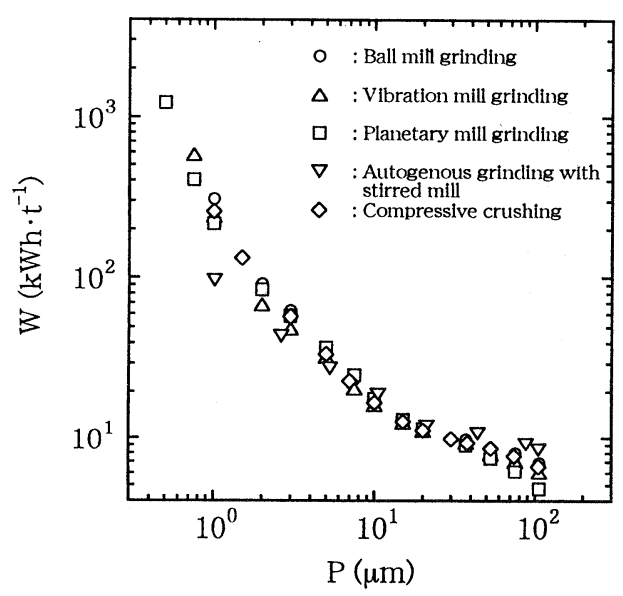

Fig. 25 Relationship between Work input and product size

\section{8. おわりに}

本研究では, 国内で自給できる天然資源である石灰 石を用いて，3種類の媒体ミルの粉砕，攪拌ミルによ る自生粉砕および粉体層の圧縮粉砕を行い, Work Index に基づく微粉砕性を検討した結果, 以下の知見 を得た。

1）石灰石の粉砕では粉砕方法に関係なく，任意の粒 子径以下の生成分率と粉砕時間, または粉研エネルギー の関係に 0 次の増加速度式が適用できた。

2) Work Index 相当数の測定により, 石灰石の粉砕
性は, 3 種類の媒体ミル粉砕および粉体層の圧縮粉砕 では, 粒子径によって変化し, 結晶粒子径の影響が大 きいことがわかった。しかし，攪拌ミルによる自生粉 砕では, 結晶粒子径 $2 \mu \mathrm{m}$ 近傍までの微粒域で粉砕 性が一定になる可能性が示された。

3）石灰石の数 $\mu \mathrm{m}$ 以下の微粉砕においては, 衝撃力, 圧縮力よりもせん断力, 摩擦力が効果的に作用するこ とを，実験に用いた粉砕方法を Work Index 相当数に よって評価することで，説明できた。

4) Work Index 相当数と Bond の仕事式を用いて, 微 粒域における石灰石の粉砕仕事量の予測を試みた結果, $2,3 \mu \mathrm{m}$ 以下の微粉砕域においては，䚓拌ミルによる 自生粉砕が有効になることを示すとともに，数 $\mu \mathrm{m}$ 〜数 $10 \mu \mathrm{m}$ の実操業レベルの粉砕に対しては, 粉砕 万法の違いが現われないことを示した。

最後に，石灰石を提供いただいた日鉄鉱業(株)，媒 体攪拌型ミルアトライターを提供いただいた三井鉱山 (株), また本研究にご協力いただいた城北化学工業 （株）に謝意を表する。

\section{Nomenclature}

$E \quad$ : grinding energy

$F \quad$ : feed size ( $80 \%$ of feed passes in microns)

$G_{\mathrm{bp}}$ : ball mill grindability $\left(\mathrm{g} \cdot \mathrm{rev}^{-1}\right)$

$J \quad$ : apparent fractional ball filling of mill volume

$K_{1}$ : first order decreasing rate constant of mass fraction of feed size $x_{\mathrm{f}}$ $\left(\min ^{-1}\right)$

$k_{0}:$ zero order increasing rate constant of product less than a size $x_{\mathrm{c}} \quad\left(\mathrm{g} \cdot \mathrm{min}^{-1}\right)$

$k_{\mathrm{xc}}$ : zero order increasing rate constant of mass fraction less than a size $x_{\mathrm{c}}$ $\left(\mathrm{min}^{-1}\right)$

$k_{\mathrm{xc}}{ }^{\prime}$ : zero order increasing rate constant of mass fraction less than a size $x_{0}$

$P$ : product size ( $=80 \%$ of product passes in microns)

$(\mu \mathrm{m})$

$P^{\prime}$ : product size ( $=80 \%$ of product less than a size $P_{1}$ passes)

$(\mu \mathrm{m})$

$P_{1} \quad$ grindability test sieve opening in microns $(\mu \mathrm{m})$ 
$Q_{\mathrm{xc}}:$ mass fraction of product less than a size $x_{0}$

$R$ : mass fraction of feed size $x_{\mathrm{f}}$

$t$ : grinding time (min)

$U$ : apparent fractional feed filling of voids volume in ball bed defined by $J$

$W$ : work input $\left(\mathrm{kWh} \cdot \mathrm{t}^{-1}\right)$

$W_{\mathrm{B}}$ : mass of balls

$W_{\mathrm{i}}$ : Bond's Work Index $\left(\mathrm{kWh} \cdot \mathrm{t}^{-1}\right)$

$W_{\mathrm{i}}(\mathrm{C})$ : constant Work Index $\left(\mathrm{kWh} \cdot \mathrm{t}^{-1}\right)$

$W_{\mathrm{i}, \mathrm{c}}$ : corresponding Work Index

$$
\left(\mu \mathrm{m}^{0.5} \cdot\left(\mathrm{g} \cdot \mathrm{min}^{-1}\right)^{-0.82}\right)
$$

$W_{\mathrm{i}, \mathrm{c}}{ }^{\prime}$ : corresponding Work Index

$$
\left(\mu \mathrm{m}^{0.5} \cdot\left(\mathrm{kg} \cdot \mathrm{J}^{-1}\right)^{-0.82}\right)
$$

$W_{\mathrm{i}, c, \text { min }}$ : minimum corresponding Work Index

$$
\left(\mu \mathrm{m}^{0.5} \cdot\left(\mathrm{g} \cdot \mathrm{min}^{-1}\right)^{-0.82}\right)
$$

$W_{\mathrm{i}, \mathrm{em} \text { min. }}$. $:$ minimum corresponding Work Index $\left(\mu \mathrm{m}^{0.5} \cdot\left(\mathrm{kg} \cdot \mathrm{J}^{-1}\right)^{-0.82}\right)$

$W_{\mathrm{i}, \mathrm{c}, \mathrm{n}} \quad$ : non-dimensional corresponding Work $\operatorname{Index}\left(=W_{\mathrm{i}, \mathrm{c}} / W_{\mathrm{i}, c, \min .}\right.$ or $\left.W_{\mathrm{i},{ }^{\prime},} / W_{\mathrm{i}, \mathrm{c}, \min .}{ }^{\prime}\right)$

$\left(W_{\mathrm{i}, \mathrm{n}, \mathrm{n}}\right)_{\mathrm{B}}$ : non-dimensional corresponding Work Index in ball mill grinding

$W_{\mathrm{s}}$ : feed mass of sample

$W_{\text {xc }}$ : mass of product less than a size $x_{\mathrm{c}}$

$x$ : particle size

$x_{\mathrm{c}} \quad$ : cut size for evaluating a grindability (= evaluating size)

$x_{\mathrm{f}} \quad$ : feed size

$(\mathrm{mm})$

\section{References}

1) Sekkaiseki Kogyo Kyokai : "Sekkaiseki No Yoto To Tokusei" (1986)

2) Kanda,Y. and E. Kimura: "Influence of Particle Shape on Ball Mill Grindability", J.Soc. Mat.Eng. Resour. Jpn., 3, 142-149 (1995)

3) Kanda, Y.,Y. Hayashi, N. Yamaguchi and T. Hasegawa: "Production of Submicron Particles of Limestone by Autogenous Grinding with a Stirred Mill”, ibid, 8, 12-20 (1995)

4) Kanda, Y. and S. Yashima: "Sekkaiseki No Rikigakuteki Bussei To Hasai, Funsai, Cho-
Bifunsai Narabini Keijyo Chosei”, Sekkaiseki, No. 275, 21-57 (1995)

5) Saito, M. : "Size Effect of Shearing Strength and Energy's Law”, Graduation Thesis, Yamagata Univ. (1969)

6) Yashima, S., Y. Kanda, T. Izumi and T. Shinozaki : "Size Effect of Single Particle Crushing”, Kagaku Kogaku, 36, 1017-1023 (1972)

7) Kanda, Y. and M. Suzuki : "Vickers Hardness of Rocks and Minerals”, J.Soc.Powder Technol.Jpn., 13, 487-489 (1976)

8) Honma, T., M. Hasegawa and Y. Asaba : "Effect of Various Factors on Grinding Using Jet Mill”, Kagaku Kogaku Ronbunsyu, 6, 527532 (1980)

9) Yashima, S. : "Funsai To Funtai Bussei", P. 58, Baifukan (1986)

10) Y.Kanda. Y. Abe and H. Sasaki : "An Examination of Ultra-Fine Grinding by Preferential Grinding”, Powder Technol., 56, 143-148 (1988)

11) Bond, F.C. : "The Third Theory of Comminution”, Trans. A.I. M. E. Min. Eng., 193, 484-494 (1952)

12) Kotake, N., H. Shoji, M. Hasegawa and Y. Kanda: "The Evaluation of the Fine Grindability of Solid Materials based on the Work Index", J.Soc. Powder Technol. Jpn., 31, 626630 (1994)

13) Kotake, N., Y. Watanabe, T. Ishizaki and Y. Kanda: "Evaluation of Fine Grindability of Ball, Vibration and Planetary Mills by Corresponding Work Index", Kagaku Kogaku Ronbunshu, 22, 106-112 (1996)

14) Ishihara, T. : "A Comparison of Work Index and Operating Work Index”, J.Min.Metal. Inst. Jpn., 81, 1064-1071 (1965)

15) Honma, E. : "Operating Work Index of Cement Grinding Mills”, J. Soc. Powder Technol. Jpn., 8, 505-512 (1971)

16) Tanaka, T. and K. Yoshimoto: "Application of Bond Theory to Large Grinding Mill”, R \& D Kobe Steel Eng. Reports, 35, 34-37 (1985) 
17) Bond, F.C.: "Confirmation of The Third Theory”, Trans. A.I. M.E. Min.Eng., 27, 139153 (1952)

18) JIS M 4002 (1976)

19) Nippon Kagaku kai: "Kagaku Sosetsu No. 48 Cho-Biryushi -Kagaku To Ouyo-”, Gakkai Syuppan Senta, p. 96 (1985)

20) Ishihara, $\mathrm{T}:$ "Results of Work Index Tests on Testing Mill”, J.Min. Metal. Inst. Jpn., 80, 924-928 (1964)

21) Arbyter, N. and U.N, Bhrany: "Correlation of Product Size, Capacity and Power in Tumbling Mills", Trans. A.I.M.E., 217, 245-252 (1960)

22) Herbest, J. A. and D. W. Fuerstenau: "The Zero Order Production of Fine Sizes in Comminution and its Implications Simulation", Trans. A.I. M.E., 241, 538-549 (1968)

23) Kanda, Y. and J. Shimoiizaka: "Kinetic Study on the Product of Grinding when the Size Distribution Follows the Gaudin-Schuhmann Equation", J.Min. Metal.Inst.Jpn., 84, 1077-1081 (1968)

24) Kwade, A and J.Schwedes: "Wet Comminution in Stirred Media Mills", KONA, No. 15, 91-102 (1997)

25) Wada, M. : "Size Distribution of Ball-Mill Products of the Yentai Aluminaus Shale" Suiyoukaishi, 10, 509-530 (1941)

26) Mori, Y. and G. Jimbo: "On the Mechanism of Ball Mill Grinding”, Kagaku Kogaku, 23, 138 (1959)

27) Yokoyama, T., K. Tamura, H. Usui and G. Jimbo: "Numerical Analysis of Movement of Balls in a Vibration Mill in Relation with Its Grinding Rate", KONA, No.11, 179-190 (1993)

28) Zhao Q. Q. and G. Jimbo: "The Effect of grinding Media on the Breakage Rate of Planetary Mill", J.Soc. Powder Technol. Jpn., 25, 603-608 (1988)

29) Shoji, K., L. G. Austin, F.Smaila, K. Brame and P. T. Lucie: "Further Studies of Ball and
Powder Filling Effects in Ball MIlling”, Powder Technol., 31, 121-126 (1982)

30) Rose.H.E. and R. M. E. Sullivan : "An Experimental Investigation of Vibration Milling", Brit. Chem. Eng., 4, 450-457 (1959)

31) Rose.H.E. : "On the Performance of HighDuty Vibration Mills", Trans. Instn. Chem. Engrs, 38, 107-121 (1960)

32) Zhao Q. Q., S. Yamada and G. Jimbo: "The Mechanism and Limit of Finess of a Planetary Mill Grinding", J.Soc. Powder Technol. Jpn., 25, 297-302 (1988)

33) Honma, T., M. Kuriyama, M. Hasegawa and Y. Kanda: "Grinding rate of a Ball Mill Operated under Centrifugal Force”, Kagaku Kogaku Ronbunshu, 11, 311-316 (1985)

34) Honma, T., M. Kuriyama and Y.Kanda: "Ball Mill Grinding Using Centrifugal Force", J. Min. Metal. Inst. Jpn., 102, 301-305 (1985)

35) Imanishi, N. : "Grindability of Iron Ore and Coal in Ore Treatment Process", R \& D Kobe Steel Eng. Reports, 35, 10-13 (1985)

36) Sikong, L., H. Hashimoto and S. Yashima : "Breakage Behavior of Fine Particles of Brittle Minerals and Coals", Powder Technol., 61, 51-57 (1990)

37) Morohashi, S.: "Fundamental Studies on Production of Ultrafine Powder by Frictional Grinding”, Doctoral Thesis, Tohoku Univ. (1987)

38) Hayashi, Y. : "Autogenous Grinding of Limestone by Stirred Mill”, Master's Thesis, Yamagata Univ. (1994)

39) Tateda, Y.: "Production of Fine Particles and Control of Particle Shape by Autogenous Grinding with Stirred Mill”, Master's Thesis, Yamagata Univ. (1998)

40) Yashima, S. : "Kagaku Kogaku No Shinpo Funryutai Kogaku”, Kagaku Kogaku Kyoukai, p. 36, Maki Shoten (1985)

41) Kanda, Y., T. Oyamada, R. Nakayama and T. Matsuo : "The Compressive Crushing of 
Brittle Materials in a Powder Bed - The Effect of Feed Size on the Production of Fine Particles-", J.Soc. Powder Technol.Jpn., 29, 824830 (1992)

42) Kanda, Y., M. Hasegawa, T. Oyamada and S. Sato: “A Fundamental Study of Preparation of Fine Particle by Compressive Crushing of Powder Bed", 2 nd. W. C. P. T. Kyoto, Part II , p. 295-302 (1990)
43) Yashima, S., Y.Kanda, T.Sasaki, M. Iijima and F. Saito: "Mechanical Properties of Brittle Materials and Their Single Fracture under Dynamic Loading”, Kagaku Kogaku, 37, 12181226 (1973)

44) Bond, F. C: "Constant Work Index from the Crack Length”, Engr. and Min. J., 164, 108-109 (1963) 